\title{
The Exploring on the Influence of Titles of WeChat Public Platform Articles on Communication Ability
}

\author{
Heyuzi Shi ${ }^{1, *}$ Zuheng Lv $^{1}$ Qimeng Sun ${ }^{2}$
}

\author{
${ }^{1}$ School of Management, Wuhan University of Technology, Wuhan, HuBei 430070, China \\ ${ }^{2}$ School of Economics, Wuhan University of Technology, Wuhan, HuBei 430070, China \\ *Corresponding author. Email: 2215479453 @qq.com
}

\begin{abstract}
In recent years, with the popularization of new media, WeChat has become an indispensable part of student life, and the importance of WeChat public platforms has also increased. The title always plays a very important role in the number of readers of the article on the WeChat public platform. This article will use the three public platforms on the campus of Wuhan University of Technology as examples to explore the impact of titles on the number of articles read on WeChat public platforms.
\end{abstract}

Keywords: communication management, ideological and political education, title, influence

\section{INTRODUCTION}

With the widespread popularization of intelligent mobile devices and the continuous upgrade of mobile networks, people are becoming more and more dependent on new media such as WeChat and Weibo, and the audience of WeChat tweets is becoming wider and wider. The campus WeChat public platform has become an important platform for colleges and universities to conduct ideological guidance and cultural dissemination and provide learning services to groups inside and outside the school. Highquality article titles can arouse the attention of the audience at the first time, increase the number of clicks, and then increase the visibility and attention of universities. In order to make the campus public platform more in line with the needs of students and strengthen students' willingness to click, this article takes some WeChat public platforms in Wuhan University of Technology as research objects, studies the influence of WeChat tweet titles on article reading, and puts forward suggestions to promote the improvement and optimization of WeChat public platforms on campus.

\section{RESEARCH METHODS AND RESEARCH ASSUMPTIONS}

This research uses a combination of quantitative and qualitative methods, using questionnaire surveys and data analysis, and has three campus public accounts that have the most extensive impact on Wuhan University of Technology: Wuhan University of Technology Youth League Committee, Analysis of exercises in Wuhan University of Technology and E-class Platform of Wuhan University of Technology. A total of 332 online questionnaires and 90 offline questionnaires were collected, of which 320 were valid online questionnaires and 83 were valid offline questionnaires. After collecting the questionnaire, the research team analyzed the data provided by the questionnaire, made assumptions, and investigated the reading data of each $\mathrm{WeChat}$ public platform based on the assumptions.

\section{DATA COLLECTION AND RESULTS ANALYSIS}

Through investigation and analysis, it is found that among the student group, the tweet title has a greater impact on the tweet click-through rate, which is reflected in the following three aspects.

In the question, "What type of push do you think the title looks like?" In this question, a total of 243 people in the online questionnaire chose "hot event reviews", 230 people chose "skill sharing," and 229 people chose opinion articles , accounting for $75.94 \%, 71.88 \%$ and $71.56 \%$ respectively. A total of 53 people in the offline questionnaire chose "hot event reviews", 50 people chose "skill dry goods sharing", and 51 people chose "viewpoint articles", accounting for $63.85 \%, 60.24 \%$, and $61.44 \%$, respectively.

In the question "What type of push does your title look like?", 238 people in the online questionnaire chose "Soul Chicken Soup", accounting for $74.38 \%$, and 77 people in the offline questionnaire chose "Soul Chicken Soup" Accounting for $92.77 \%$.

In the question "What do you think should be promoted in addition to campus news and information?" In this question, a total of 245 online questionnaires chose "life related" and 178 people chose "learning related", accounting for $76.56 \%, 55.63 \% ; 72$ people in the offline questionnaire chose "life related" and 33 people chose "learning related", accounting for 86.74 and $39.75 \%$ respectively.

In this regard, we make the following assumptions: 
(4) The content of the WeChat tweet title is related to one's

(1) The hottest vocabulary in the title can make people read more, but if the tweet "lags behind", the willingness to click will decrease, and even get bored.

(2) The title has a certain amount of thinking, or it can present a direct point of view, which is more attractive to students to read.

(3) If the general content of the tweet cannot be determined from the title, students are often reluctant to click. favorite area or related to life, which is likely to attract students' interest.

(5) The students' intention to open the head of the chicken soup tweet is very low.

According to the hypothesis, the reading data of three public platforms were collected and analyzed:

Table 1 Collection of reading numbers

\begin{tabular}{|c|c|c|c|}
\hline WeChat public platform & Title & Number of readers & Classification \\
\hline \multirow{12}{*}{$\begin{array}{c}\text { Youth League Committee } \\
\text { of Wuhan University of } \\
\text { Technology }\end{array}$} & You're so good don't lose to yourself & 2447 & \multirow{4}{*}{$\begin{array}{l}\text { Chicken Soup } \\
\text { for the Mind }\end{array}$} \\
\hline & Don't make your regrets and fears & 3192 & \\
\hline & To me who is witnessing my growth & 2725 & \\
\hline & I will be your pride & 3591 & \\
\hline & $\begin{array}{c}\text { Why is the "greenest college" Wuhan } \\
\text { University of Technology }\end{array}$ & 7992 & \multirow{4}{*}{ Study and Life } \\
\hline & Free Wuhan Metro Card? !! The truth is here & $2 \mathrm{~W}$ & \\
\hline & $\begin{array}{l}\text { They used } 30,000 \text { square meters to create this } \\
\text { beauty! }\end{array}$ & 9575 & \\
\hline & $\begin{array}{c}\text { "Mom, I eat very well at Wuhan University } \\
\text { of Technology, please rest assured!" }\end{array}$ & 7853 & \\
\hline & $\begin{array}{l}\text { Youth singing confession to the motherland! } \\
\text { @ Huazhong Agricultural University Come } \\
\text { on! }\end{array}$ & 6043 & \multirow{4}{*}{ Hot News } \\
\hline & $\begin{array}{l}\text { Demystified! It turns out you are like this } \\
\text { opening ceremony of the military games }\end{array}$ & 3506 & \\
\hline & $\begin{array}{c}\text { Countdown! National Day military parade } \\
\text { viewing guide is here }\end{array}$ & 7335 & \\
\hline & $\begin{array}{l}\text { good news! Wuhan University of Technology } \\
\text { again holds the "Challenge Cup" national } \\
\text { competition "Winning Cup"! }\end{array}$ & 5474 & \\
\hline \multirow{10}{*}{$\begin{array}{c}\text { Analysis of exercises in } \\
\text { Wuhan University of } \\
\text { Technology }\end{array}$} & Meet again & 560 & \multirow{4}{*}{$\begin{array}{l}\text { Chicken Soup } \\
\text { for the Mind }\end{array}$} \\
\hline & $\begin{array}{l}\text { The rest of the way, after all, you have to } \\
\text { learn to go by yourself ... }\end{array}$ & 787 & \\
\hline & Small town youth & 481 & \\
\hline & Don't be afraid, just lonely! & 657 & \\
\hline & $\begin{array}{l}\text { Observation of students staying up late at } \\
\text { Wuhan University of Technology }\end{array}$ & 2196 & \multirow{4}{*}{ Study and Life } \\
\hline & Goodbye, Shengsheng Food City & 3736 & \\
\hline & $\begin{array}{l}\text { What do girls think about when they run } 800 \\
\text { meters? }\end{array}$ & 1092 & \\
\hline & $\begin{array}{c}\text { Teach you a trick to solve advanced } \\
\text { mathematics }\end{array}$ & 741 & \\
\hline & $\begin{array}{l}\text { Shake your shoulders together at Wuhan } \\
\text { University of Technology? }\end{array}$ & 1159 & \multirow[t]{2}{*}{ Hot News } \\
\hline & 2017 VS 2019 & 1067 & \\
\hline \multirow{4}{*}{$\begin{array}{c}\text { E-class Platform of } \\
\text { Wuhan University of } \\
\text { Technology }\end{array}$} & $\begin{array}{l}\text { As adults, every label you tear off takes a } \\
\text { part of yourself }\end{array}$ & 642 & \multirow{3}{*}{$\begin{array}{l}\text { Chicken Soup } \\
\text { for the Mind }\end{array}$} \\
\hline & Yellow Crane Tower in Poems & 230 & \\
\hline & Your figure is in my heart & 303 & \\
\hline & $\begin{array}{l}\text { Still sad to not grab the best viewing area? } \\
\text { Xiaoyi takes you to grab a ticket to watch } \\
\text { "Natsume's Book of Friends" }\end{array}$ & 286 & Study and Life \\
\hline
\end{tabular}




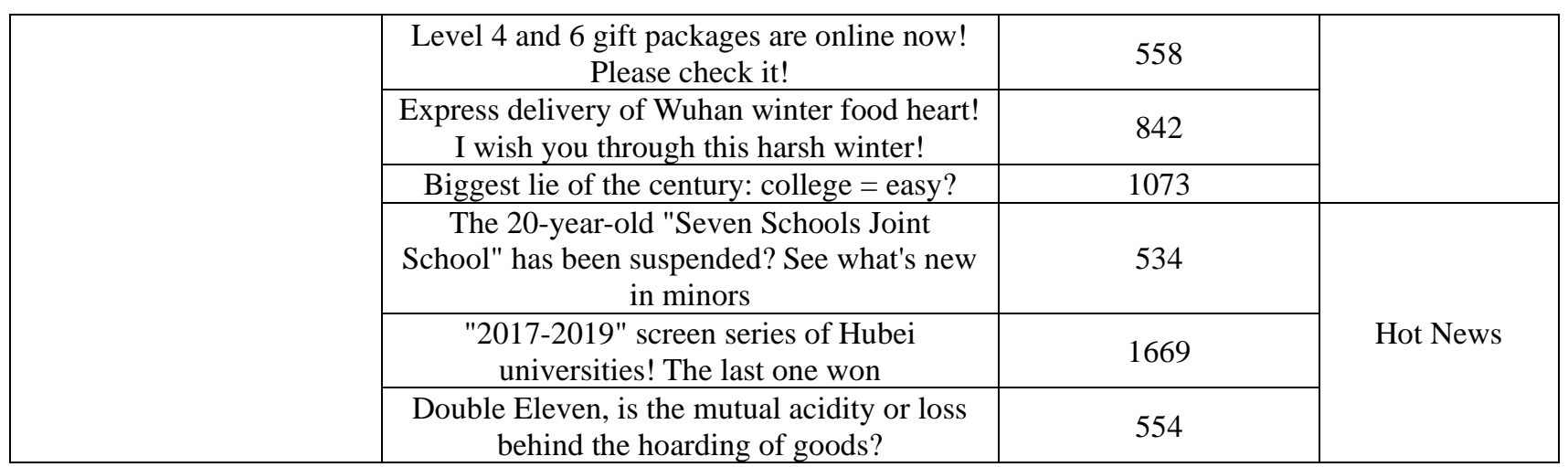

\section{CONCLUSION}

In summary, if the title of the push message is not attractive, it may lose many subscribers and reduce the influence of the organization. WeChat tweets must first do a good title. The authors of WeChat tweets are understandable in pursuit of a good title, but they must also master the level. It is best to use a variety of elements in the formulation of the topic. For example, the topic includes hot topics and your own views, which can attract clicks. Introduction of professional dry goods can be based on the needs of students. Of course, a good WeChat tweet is not only a good title, but also a guarantee of content. Only in this way can a better communication effect be achieved. Here are some suggestions:

(1) The title is consistent with recent hot issues. Hot issues are the focus of students' attention, especially on campus. Hot topic tweets, like news reports, need to pay attention to the timeliness of the news. The popularity of hot topics will generally decline within 3 days. If the hot topic declines, everyone will see a lot of repetitive content, the willingness to read will decline, and even get bored. Pay attention to the timeliness when formulating the content and title of the tweet.

(2) The title should be consistent with the student's area of interest or life. When content related to their own lives appears, the students keep a high interest in the WeChat tweet title.

(3) The headline note is concise and clear: our brains will be easier to understand and have better predictions or grasp of the content of the tweets.

(4) Try to avoid "wrong questions". In order to increase the attractiveness of the topic, the content may not be very relevant to the content when formulating the topic, but the quality of the content must also be ensured. This can attract the click rate and the effect will be better. If the quality of the content is not controlled, it will be difficult for the audience to read the entire content and even affect the subsequent tweets.

(5) Chicken soup tweets are close to saturation. Students want to get dry goods and improve their knowledge or skills in a short period of time, instead of "pastoral pastoral" style appeasement.
(6) The title and content must be thoughtful. As fragmented reading goes deeper into life, students want to be inspired by ideas in a short period of time. This requires content to be professional, and try to avoid "old-fashioned talk."

(7) The public account keeps the daily frequency of the best update, which can not only keep the followers active, but also have sufficient time to conceive the next tweet to ensure the quality of the tweet.

\section{REFERENCES}

[1] Guo Mengyun, Zhou Ping. Usual means and criticism of WeChat tweet "Title Party" [J]. Tan of Humanities, 2018 (00): 228-239.

[2] Zhang Lu. An analysis of the influence of WeChat tweet titles on people 's willingness to click on [J]. Southeast Communication, 2017 (06): 64-67.

[3] Xia Deqin. Research on University WeChat's Communication of University Image [D]. Northwest University, 2017.

[4] Zhang Shuhua, Yang Jier. Probe into the Writing of News Headlines Pushed by WeChat Subscription Numbers: A Case Study of Beijing WeChat Subscription Numbers [J]. Science \& Technology Communication, 2016, 8 (18): 138-139.

[5] Hou Junyu. The harm of WeChat public account "Title Party" and its countermeasures [J]. Media Forum, 2019, 2 (18): 168-169. 